\title{
Comparative Analysis of Banking Financial Performance Pre and Post Covid-19 Pandemic
}

Triska Dewi Pramitasari Universitas Abdurachman Saleh Situbondo, Indonesia triska_dewi@unars.ac.id

\begin{abstract}
Covid-19 struck the Indonesian banking industry in particular ASEAN, through the weaker economic growth, which resulted in a slowdown in credit growth and eventually reduce profitability. This study aimed to analyze the financial performance of banks before and after the occurrence of a covid-19 pandemic and formulate alternative strategies to improve the financial performance of Indonesian banks. The study sample consisted of four banks with saturated sampling method (census) are owned banks (State Bank) listed on the Stock Exchange Indonesia. The data in this research is secondary data obtained from the bank's annual report period 2019 until the second quarter of 2020 which is accessed via the IDX website. Performance is measured using the six financial ratios namely ROA, BOPO, NPL, NIM, CAR and LDR with different test analysis method (Paired T-Test). The study found that in the form of financial ratios ROA, BOPO, CAR and LDR pre and post Covid-19 pandemics have significantly different values, while the NPL and NIM did not differ significantly.
\end{abstract}

Keywords: Financial Performance; Covid-19 Pandemic; Banking; Financial Ratios

\section{INTRODUCTION}

Covid-19 pandemic have a major impact on the economy of many countries in the world, including Indonesia. The most apparent when it is shaken global stock markets to a low point that also occurred in the Indonesia Stock Exchange. The manufacturing industry, SMEs, the financial industry to the individual income people had come crashing waves of the epidemic. No wonder if there are many countries that ultimately provide economic stimulus in order to reduce the impact of the economic downturn (Ucu, 2020). Impact Covid-19 appears to impact on all sectors, especially sectors of the economy. Economic growth slowed. This is due to the continued expansion of the distribution Covid-19 not only in the country but also abroad. This delay was marked by worsening external environmental conditions and weakening domestic demand in line with declining business and consumer sentiment (Putri, 2020). 
Several business sectors were affected by the Covid-19 pandemic, including the banking sector. Covid-19 hit the ASEAN banking sector, including Indonesia, through weakening economic growth, which resulted in a slowdown in credit growth and led to a decline in banking profitability. Therefore we can conclude banking financial performance will weaken along with the widespread distribution of Covid-19 (Syafina, 2020).

Banking financial performance can be used as a tool to analyze operational activities in the banking sector, whether all activities have gone according to plan or not. In addition, banking financial performance can also be used as material for evaluating banks for a certain period. Financial performance measure one using financial statement analysis. The financial statements in this case needs to be analyzed in order to facilitate the reader obtain financial information of banks in a given period. Financial statement analysis can be done by calculating financial ratios derived from the financial statements (Munawir, 2012).

There are many indicators used in assessing the effectiveness of banking performance. Return on Asset (ROA) is a type of profitability ratio used as an indicator in assessing the effectiveness of a bank in generating profits by utilizing assets owned by the bank. Assessment of financial performance can also be measured by the ratio of operating expenses to operating income (BOPO), this ratio is used as an indicator for the bank in assessing the bank's operational costs that must be spent to obtain operating income. The next variable is Non Performing Loans (NPL) as an indicator of management in managing credit extended by banks. The ability of the bank's management in managing its productive assets to generate net interest income can be measured using the ratio of Net Interest Margin (NIM). Ratio Capital Adequacy Ratio (CAR) was used to measure the level of risk of a bank because it reflects the level of capital adequacy that is used as a container for the risk of loss. Meanwhile, as a function of channeling funds to the public, the use of Loan to Deposit Ratio (LDR) is used as an indicator to measure the performance of banks in terms of total loans extended by banks (Fahmi, 2013: 248).

The object of this research are owned banks known as the Association of State-Owned Banks consisting of Bank Mandiri (Persero) Tbk, Bank Negara Indonesia (Persero) Tbk., Bank Rakyat Indonesia (Persero) Tbk., and Bank Tabungan Negara (Persero) Tbk. When the Covid-19 pandemic occurred, there was a phenomenon in the banking world where many countries experienced an economic downturn, but not banking in Indonesia, especially the Association of State-Owned Banks listed on the Stock Exchange.

During the hearing with the House of Representatives Commission VI, President Director of PT Bank Rakyat Indonesia (Persero) Tbk. Sunarso call Persero bank's performance until the first quarter of 2020 recorded still positive. Recorded total bank credit incorporated in the State-Owned Banks Association grew by $11.03 \%$ on an annual basis or year on year (yoy) to Rp 2469.32 trillion. Total assets grew 7.09\%, loans grew $11.03 \%$. Meanwhile, in terms of raising funds recorded total third party funds (DPK) per March 
2020 is also still growing double digit 10.23\% yoy to Rp 2611.45 trillion. (Sitanggang, 2020). With this phenomenon, the motivation to be appointed is a gap phenomenon in this study by focusing on state-owned banks due to the need for research boundaries. This kind of research has also been carried out by several previous studies, where these studies suggest a research gap on the comparison of banking financial performance before and after an event (in different periods), including the results of research by Cholifah (2017) and Prima (2018), research by Kinasih (2013) and Dewi (2016), research by Rasim (2015) and Utami (2013), research by Ziyad (2010) and Prima (2018), research by Novriza (2012) and Rahmawati (2015), and research by Lombogia ( 2015) and Widiani (2016).

In the research results of Dewi (2016), it is stated that there is no significant difference in financial performance, in this case the value of ROA before and after the acquisition. The increase in total assets occurred after the acquisition because the company received an injection of funds from the bank. The increase in net profit earned was still fluctuating, but the changes in profit were not significant. The results of this study are supported by Utami (2013), Cholifah (2017), and Salin (2018). However, the results of this study are not in line with the results of research by Ziyad (2010) and Kurniasari (2017) which show that there is a significant difference in the value of ROA between before and after an event (in different periods).

\section{THEORETICAL REVIEW}

\section{Bank}

Bank is a financial institution whose main activities to collect funds from the public and distribute the funds back to the community and provide other banking services (Kashmir, 2016). Meanwhile, based on the statement of Financial Accounting Standards (SFAS) No. 31, the definition of the Bank is an institution that acts as a financial intermediary between parties who have surplus funds and those who need funds, as well as a functioning institution expedite payment traffic. It can be concluded the bank is a financial institution whose main activity is collecting funds from the public in the form of deposits and then distribute the funds to the community in the form of loans, and provide other banking services.

\section{Financial Performance}

Financial performance is one of the tools to assess the success of a bank. A bank can be said to be successful if it can achieve its banking objectives maximally, either in the form of profit or market share. In addition, banks can use financial performance for financial planning and forecasting in the future. According Kusumawati (2012) The financial performance is an analytical technique used to assess whether the banking activities activities carried out has been going well and according to the rules. Fahmi (2013) states that the measurement of financial performance of banks has the purpose to measure 
and assess the level of effectiveness and efficiency of banking in conducting its operational activities.

\section{Financial Statement Analysis}

Munawir (2012) explains that financial statement analysis is a process of processing data on financial reports so that readers can easily understand and understand them. According to Fahmi (2013) The main purpose of financial statement analysis is to determine the financial performance of banks in a given period. Financial statement analysis can be used as a comparison tool between companies engaged in the same industry. Munawir (2012) explains that there are two methods used in analyzing the financial statements of the vertical and horizontal method. The difference between the two methods is that the vertical method only compares accounts available in the financial statements and only uses one financial reporting period, while the horizontal method of analysis is by comparing the financial statements over time or period so that differences in financial performance can be seen clearly.

\section{METHODOLOGY}

This research uses a comparative quantitative approach. A comparative research study comparing the presence of one or more variables in a sample or a different time (sugiyono, 2014). Based on this description, this study compares the financial performance of banks before and after the covid-19 pandemic.

The population is the entire set of data that is possible to be observed or recorded by researchers (Morissan, 2012). The population in this study were four banks listed on the Indonesian Stock Exchange. The sample is a number or part of a certain sample taken from the population which is then examined in detail (Sugiyono, 2014). The sampling method using saturated sampling method (census). According Sugiyono (2014), this technique is a sampling technique when all members of the population used as a sample. This can be done because the population used is relatively small (less than 30). So the sample in this study amounted to four banks, namely Bank Mandiri (Persero) Tbk, Bank Negara Indonesia (Persero) Tbk., Bank Rakyat Indonesia (Persero) Tbk., and Bank Tabungan Negara (Persero) Tbk.

The data in this research is secondary data. This secondary data is obtained from the banking quarter annual report which is accessed through the Indonesian Stock Exchange website (www.idx.co.id). The data collection technique used is the documentation technique through the collection of data on the financial statements of State-Owned Banks for the period 2019 to the second quarter of 2020. Data is obtained by observing, recording and studying descriptions of books, journals, theses, and other literature related to research conducted as well as from the quarterly financial statements of state-owned banks for the period 2019 to the second quarter of 2020. 
The research variable is an attribute, nature or value of people, objects or activities that have certain variations that are determined by researchers to study and draw conclusions (Sugiyono, 2014). The variables used in this study are the variables of banking financial performance as measured by ROA, BOPO, NPL, NIM, CAR and LDR. Details of the identification and measurement of research variables are presented in Table 1.

Table 1. Identification and Measurement of Variables

\begin{tabular}{lll}
\hline \multicolumn{1}{c}{ Variable } & Symbol & \multicolumn{1}{c}{ Measurement } \\
\hline Return On Assets & ROA & $\begin{array}{l}\text { the ratio between net income by total assets } \\
\text { expressed as a percentage (\%) by using a ratio } \\
\text { scale }\end{array}$ \\
$\begin{array}{l}\text { Operating Expenses } \\
\text { Op } \begin{array}{l}\text { Operating } \\
\text { Income }\end{array}\end{array}$ & BOPO & $\begin{array}{l}\text { the ratio between operating expenses to } \\
\text { operating income expressed as a percentage } \\
(\%) \text { by using a ratio scale }\end{array}$ \\
\hline $\begin{array}{l}\text { Non Performing } \\
\text { Loan }\end{array}$ & NPL & $\begin{array}{l}\text { the ratio between the number of non- } \\
\text { performing loans and the total loans expressed } \\
\text { in percentage (\%) using a ratio scale }\end{array}$ \\
\hline Net Interest Margin & NIM & $\begin{array}{l}\text { the ratio between net interest income to } \\
\text { average earning assets expressed as a } \\
\text { percentage (\%) by using a ratio scale }\end{array}$ \\
\hline $\begin{array}{l}\text { Capital Adequancy } \\
\text { Ratio }\end{array}$ & CAR & $\begin{array}{l}\text { the ratio between capital to risk weighted } \\
\text { asset expressed as a percentage (\%) by using a } \\
\text { ratio scale }\end{array}$ \\
\hline $\begin{array}{l}\text { Loan to Deposite } \\
\text { Ratio }\end{array}$ & LDR & $\begin{array}{l}\text { the ratio between credit and third party funds } \\
\text { expressed in percentage (\%) using a ratio scale }\end{array}$ \\
\hline
\end{tabular}

Due to a comparative study, the data analysis techniques used are different test (Paired Sample T-Test), which previously performed the Kolmogorov-Smirnov normality test to determine whether the data were normally distributed (parametric) or not (nonparametric). The value of a used in the Kolmogorov-Smirnov test was $5 \%$, which, if the Sig. $>5 \%$ then the data is normally distributed, but if the value is Sig. $<5 \%$, then the data are not normally distributed. Through the Paired Sample T-Test with SPSS 20, the results that will appear are the average value of each data, the correlation value, and hypothesis testing with $t$-count against $t$-table or through $p$-value (Sig.) So that obtained results from hypothesis testing. In a test of the hypothesis is:

Ho: $\mu 1=\mu 2$ (average pre- and post- Covid-19 pandemic is the same)

$\mathrm{H} 1: \mu 1 \neq \mu 2$ (average pre- and post- Covid-19 pandemic is different) 
The basis for decision making is as follows:

a. $t$ count $>t$ table (Sig. $<a$ ), then Ho is rejected or Ha is accepted (there is a significant difference)

b. $\mathrm{t}$ count $<\mathrm{t}$ table (Sig.> $\mathrm{a}$ ), then $\mathrm{Ho}$ is accepted or $\mathrm{Ha}$ is rejected (there is no significant difference) (Kuncoro, 2010).

\section{RESEARCH RESULTS}

Results of data normality test six variables (ROA, ROA, NPL, NIM, CAR and LDR) to the four-owned banks (bank Mandiri, BNI, BRI and BTN) using the Kolmogorov-Smirnov (KS) non-parametric statistical test are described in the Table 2.

Tabel 2. Data Normality Test Results

\begin{tabular}{ccccc}
\hline Variable & $\begin{array}{c}\text { Sig. } \\
\text { Kolmogorov- } \\
\text { Smirnov Bank } \\
\text { Mandiri }\end{array}$ & $\begin{array}{c}\text { Sig. } \\
\text { Kolmogorov- } \\
\text { Smirnov BNI }\end{array}$ & $\begin{array}{c}\text { Sig. } \\
\text { Kolmogorov- } \\
\text { Smirnov BRI }\end{array}$ & $\begin{array}{c}\text { Sig. } \\
\text { Kolmogorov- } \\
\text { Smirnov } \\
\text { BTN }\end{array}$ \\
\hline ROA & 0.668 & 0.512 & 0.662 & 0.311 \\
\hline BOPO & 0.584 & 0.371 & 0.219 & 0.212 \\
\hline NPL & 0.091 & 0.077 & 0.301 & 0.043 \\
\hline NIM & 0.072 & 0.103 & 0.092 & 0.019 \\
\hline CAR & 0.112 & 0.119 & 0.115 & 0.082 \\
\hline LDR & 0.305 & 0.190 & 0.231 & 0.173 \\
\hline
\end{tabular}

Table 2. illustrates that all variables (ROA, BOPO, NPL, NIM, CAR and LDR) in Bank Mandiri (Persero) Tbk., Bank Negara Indonesia (Persero) Tbk. and Bank Rakyat Indonesia (Persero) Tbk. has a significant value above the sig level. (a), so that Ho is accepted, which means the data is normally distributed. Meanwhile, in Bank Tabungan Negara (Persero) Tbk. there are four variables (ROA, BOPO, CAR and LDR) which have a significant value above the sig level. ( $\alpha$ ), so that Ho is accepted, which means the data is normally distributed. However, there are two variables (NPL and NIM) which indicate that the data is not normally distributed where the significant value is smaller than the sig level. (a), so that Ho is rejected. An alternative that can be done is to transform the data in the form of a z-score to produce all data that is normally distributed.

The results of the Paired Sample T-Test for six variables (ROA, BOPO, NPL, NIM, CAR and LDR) in four state-owned banks (Bank Mandiri, BNI, BRI, and BTN) are described in the Table 3. 
Table 3. Different Test Results (Paired Sample T-Test)

\begin{tabular}{lcccccc}
\hline \multicolumn{1}{c}{ Bank } & $\begin{array}{c}\text { Sig. } \\
\text { ROA }\end{array}$ & $\begin{array}{c}\text { Sig. } \\
\text { BOPO }\end{array}$ & $\begin{array}{c}\text { Sig. } \\
\text { NPL }\end{array}$ & $\begin{array}{c}\text { Sig. } \\
\text { NIM }\end{array}$ & $\begin{array}{c}\text { Sig. } \\
\text { CAR }\end{array}$ & $\begin{array}{c}\text { Sig. } \\
\text { LDR }\end{array}$ \\
\hline Bank Mandiri & 0.012 & 0.015 & 0.042 & 0.228 & 0.008 & 0.027 \\
\hline BNI & 0.027 & 0.029 & 0.081 & 0.591 & 0.025 & 0.044 \\
\hline BRI & 0.022 & 0.003 & 0.279 & 0.157 & 0.011 & 0.017 \\
\hline BTN & 0.046 & 0.103 & 0.116 & 0.445 & 0.042 & 0.038 \\
\hline
\end{tabular}

Different test results in Table 3 indicate that ROA on a four-owned banks (Bank Mandiri, BNI, BRI and BTN) has the Sig. below the level of significant ( $\alpha=5 \%$ ), then Ho is rejected, which means that there are significant differences between the financial performance of banking pre and post Covid-19 pandemic, where decline the post-Covid-19 pandemic.

BOPO variable at Bank Mandiri, BNI, and BRI have a Sig. below the level of significant ( $\alpha$ $=5 \%$ ), then $\mathrm{Ho}$ is rejected, which means that there are significant differences between the financial performance of banking pre and post Covid-19 pandemic. Whereas in BTN, the BOPO variable has a Sig value. above the level of significant ( $\alpha=5 \%$ ), then Ho is accepted, which means that there are no significant differences between the financial performance of banking pre and post Covid-19 pandemic. Thus, it can be concluded that the value of BOPO at state-owned banks tends to have a significant difference (experiencing an increase after the Covid-19 pandemic).

NPL variable at Bank Mandiri has a Sig value. below the level of significant ( $\alpha=5 \%$ ), then Ho is rejected, which means that there are significant differences between the financial performance of banking pre and post Covid-19 pandemic. While at BNI, BRI and BTN, NPL variable has a value of Sig. above the level of significant $(\alpha=5 \%)$, then $\mathrm{Ho}$ is accepted, which means that there is no significant difference between the financial performance of banks pre and post Covid-19 pandemic. Thus, it can be concluded that the NPL value at state-owned banks tends not to have a significant difference (experiencing a decrease but not significantly after Covid-19 pandemic).

NIM variable in four state-owned banks (Bank Mandiri, BNI, BRI, and BTN) has a Sig. above the level of significant ( $\alpha=5 \%$ ), then Ho is accepted, which means that there is no significant difference between the financial performance of banking pre and post Covid19 pandemic (but not significant decrease post Covid-19 pandemic).

CAR variable in four state-owned banks (Bank Mandiri, BNI, BRI, and BTN) has a Sig. below the level of significant ( $\alpha=5 \%$ ), then Ho is rejected, which means that there are significant differences between the financial performance of banking pre and post Covid-19 pandemic (decrease post Covid-19 pandemic).

LDR variable in four state-owned banks (Bank Mandiri, BNI, BRI, and BTN) has a Sig. below the level of significant ( $\alpha=5 \%$ ), then Ho is rejected, which means that there are 
significant differences between the financial performance of banking pre and post Covid-19 pandemic (decrease post Covid-19 pandemic).

\section{DISCUSSION}

\section{Comparison Value of Return on Assets (ROA) Pre and Post Covid-19 Pandemic}

Return on Asset (ROA) is an indicator of a company's profitability. This ratio indicates the extent to which investments can provide returns that correspond to what had been expected where the actual investment amounting to asset a company has invested (Fahmi, 2013). The analysis showed that ROA on a four-owned banks (Bank Mandiri, BNI, BRI and BTN) has a significant parameter at a significant level of $5 \%$. This indicates that there are significant differences between the financial performance of banking pre and post Covid-19 pandemic, where the value of ROA has decreased after Covid-19 pandemic.

The results of this study are consistent with the results from Ziyad (2010), Sisbintari (2012), Alam (2013), Kinasih (2013), Rahmawati (2015), Widiani (2016), Kurniasari (2017), Kresmiati (2017), and Prima (2018) which shows that there is a significant difference in the ROA value between before and after an event (in different periods). But this result is not consistent with the results of Utami (2013), Dewi (2016), Cholifah (2017), and Salin (2018) which showed that there was no differences were significant at the ROA between before and after an event (in different periods).

The difference in the results of the study occurred because in this study there was a significant decrease in the value of ROA. This is due to a decrease in credit extended by banks, so that the profits achieved by banks are also getting lower. Credit easing as the economy weakened the impact of the post Covid-19 pandemic. The decline in ROA ratio describes the growing size of the profit generated by the bank. A decrease in ROA indicates a decline in bank profitability.

\section{Comparison Value of Operating Expenses to Operating Income (BOPO) Pre and Post Covid-19 Pandemic}

The efficiency ratio or Operating Expenses to Operating Income (BOPO) is used to measure the ability of bank management in controlling operating expenses to operating income. The smaller the BOPO ratio, the more efficient the operational costs incurred by the bank so that the possibility of a bank in a problematic condition is getting smaller (Hasanah, 2011).

The analysis showed that BOPO the four-owned banks (Bank Mandiri, BNI, BRI and BTN) has a significant parameter at a significance level of $5 \%$. This indicates that there are significant differences between the financial performance of banking pre and post Covid-19 pandemic, where the value of BOPO has increased post Covid-19 pandemic. 
The results of this study are consistent with the results of Novriza (2012), Kinasih (2013), Widiani (2016), Cholifah (2017), Kresmiati (2017), and Kurniasari (2017) which shows that there are differences significant at a value BOPO between before and after an event (in different periods). But this result is not consistent with the results of Utami (2013), Dewi (2016), and Prima (2018) which showed that there was no difference significant at a BOPO value between before and after an event (in different periods).

The difference in research results occurred because in this study there was a significant increase in the BOPO value. This is due to an increase in operating expenses which is higher than the increase in operating income. The increase in BOPO indicates a decrease in bank profitability, because the increase in BOPO results in less efficient operating costs incurred to earn income. In other words, after the Covid-19 pandemic the use of operational costs to obtain operating income at state-owned banks was less effective.

\section{Comparison Value of Non Performing Loan (NPL) Pre and Post Covid-19 Pandemic}

The Non Performing Loan (NPL) ratio is an indicator of credit risk, which indicates the ability of the bank's management in managing the loans granted by the bank. NPL is a key indicator in assessing the performance of the bank. One of the functions of banks is as intermediary institution or liaison between parties who have excess funds to those in need of funds. Bank Indonesia (BI) through Bank Indonesia Regulation (PBI) stipulates that the ratio of non-performing loans (NPL) is $5 \%$, so the higher this ratio the more worse credit quality of the banks that cause bad debts, the greater the likelihood of a bank in a state the greater problem and enable the achievement of the lower income (Nasser, 2013).

The analysis showed that the NPL variables in the four state-owned banks (Bank Mandiri, $\mathrm{BNI}, \mathrm{BRI}$ and BTN) has the parameter is not significant at the $5 \%$ significant level. This indicates that there is not significant difference between the banking financial performance pre and post Covid 19 pandemic.

The results of this study are consistent with the results of Utami (2013), Lombogia (2015), Dewi (2016), Cholifah (2017), and Prima (2018) which showed that there was no differences were significant at NPL value between before and after the an events (in different periods). But this result is not consistent with the results of Rasim (2015) and Widiani (2016), which indicates that there are significant differences in NPL value between before and after an event (in different periods).

Differences occur because the research results in this study there is impairment of NPL are not significant, in other words there is no difference. This indicates that the stateowned banks able to cope with credit problems occur, thus the better the bank's condition. The decline in NPL value reflects the bank's achievement in improving the quality of the loan portfolio through the application of prudential principles in the credit approval process. In addition, the bank is always consistent in applying a disciplined 
approach, namely funding before lending" in order to ensure that the bank's liquidity is always taken into consideration before making a decision related to a loan.

\section{Comparison Value of Net Interest Margin (NIM) Pre and Post Covid-19 Pandemic}

The Net Interest Margin (NIM) ratio is an indicator to measure the ability of bank management to manage its productive assets in order to generate net interest income. The higher the NIM ratio, the higher the interest income on productive assets managed by the bank so that the possibility of a bank in a problematic condition will be smaller (Dendawijaya, 2013).

The analysis showed that the NIM variables on a four state-owned banks (Bank Mandiri, BNI, BRI and BTN) has the parameter is not significant at the $5 \%$ significant level. This indicates that there is no significant difference between the banking financial performance pre and post Covid 19 pandemic.

The results of this study are consistent with the results of Kinasih (2013) which showed that there was no significant difference in NIM value between before and after an event (in different periods). But this result is not consistent with the results of Ziyad (2010) and Prima (2018) which shows that there are differences significant at NIM value between before and after an event (in different periods).

Differences occur because the research results in this study, there were no impairment NIM significant, in other words there is no difference. The decline in NIM due to an increase in interest expense greater than pre-Covid-19 pandemic. This indicates that with the decline in NIM, banking intermediation is still not optimal, and banks are less able to manage their productive assets to generate net interest income post-Covid-19 pandemic.

\section{Comparison Value of Capital Adequacy Ratio (CAR) Pre and Post Covid-19 Pandemic}

The Capital Adequacy Ratio (CAR) is a capital adequacy ratio that shows the ability of banks to provide funds to overcome possible risk of loss. This ratio is important because to maintain the CAR at the safe limit (minimum $8 \%$ ), means also protect clients and maintain the stability of the financial system as a whole. The greater the CAR value reflects the better the ability of banks to face possible risk of loss (Fahmi, 2013).

The analysis showed that the CAR variables on the four state-owned banks (Bank Mandiri, BNI, BRI and BTN) has a significant parameter at a significant level of $5 \%$. This indicates that there are significant differences between the banking financial performance pre and post Covid-19 pandemic, where the CAR value decreased of the post-Covid-19pandemic.

The results of this study are consistent with the results of Ziyad (2010), Novriza (2012), Sisbintari (2012), Utami (2013), Cholifah (2017), and Salin (2018) which shows that there 
are differences significant in the CAR between before and after the an event (in different periods). But this result is not consistent with the results of Rahmawati (2015), Kresmiati (2017), and Prima (2018) which showed that there was no differences were significant at the CAR between before and after an event (in different periods).

Differences occur because the research results in this study are the significant decline in the CAR. CAR impairment occurs by a decline in bank profitability caused by the decline in bank lending. This indicates that the lack of ability of banks in the face of possible risk of loss.

\section{Comparison Value of Loan to Deposit Ratio (LDR) Pre and Post Covid-19 Pandemic}

The Loan to Deposits Ratio (LDR) is a ratio that measures a bank's ability to meet shortterm liabilities (liquidity) by dividing total loans to total Third Party Funds (TPF). Liquidity needs to be managed in order to meet bank needs when customers take their funds and distribute loans (credit) to debtors. Increasing the value of LDR is too high indicates that banks do not have sufficient liquidity to cover its liabilities (DPK). Conversely, the lower LDR value indicates that banks have adequate liquidity but with lower income, because the banking sector's income is obtained through lending (Fahmi, 2013).

The analysis showed that the LDR variables on the four state-owned banks (Bank Mandiri, BNI, BRI and BTN) has a significant parameter at a significant level of $5 \%$. This indicates that there are significant differences between the banking financial performance pre and post Covid-19 pandemic, where the LDR value decreased of the post- Covid-19 pandemic.

The results of this study are consistent with the results of Sisbintari (2012), Alam (2013), Utami (2013), Widiani (2016), and Prima (2018) which shows that there are differences significant at LDR value between before and after an event (in different periods). But this result is not consistent with the results of Novriza (2012), Kinasih (2013), Lombogia (2015), Dewi (2016), and Cholifah (2017) which showed that there was no differences were significant at LDR value between before and after an event (in different periods).

Differences occur because the research results in this study are the significant decline in the LDR value. This is due to a decline in the number of loans compared to the thirdparty funds (DPK) from before the onset of the Covid-19 pandemic. This indicates that the reduction in the amount of credit granted to the public is not followed by a decrease in the number of third-party funds that will lead to the decrease in the profit opportunities of bank lending.

\section{CONCLUSION}

The conclusion of this study is a comparison of financial ratios at Bank Mandiri (Persero) Tbk, Bank Negara Indonesia (Persero) Tbk., Bank Rakyat Indonesia (Persero) Tbk., and 
Bank Tabungan Negara (Persero) Tbk. in the form of ROA, BOPO, CAR and LDR pre and post Covid-19 pandemic shows that tend to have significantly different values, while the NPL and NIM did not differ significantly. In general, there are significant differences in the banking financial performance of pre and post Covid-19 pandemic. There are several suggestions that can be given by researchers to state-owned banks and similar further research. Need for increased selection and intensive analysis in lending by the banks so as to reduce credit risk and improve the income on the loan interest. In addition, it is expected the maximization of investment and efficient use of operating costs, so that the banking financial performance will remain optimally unaffected by the Covid-19 pandemic. As for further research, because this research uses only state-owned banks during the period from 2019 to 2020 with six variables of the study, expected to carry out research on the banking sector as a whole with a range longer period and using more research variables, so as to improve the quality of research results.

\section{REFERENCES}

Alam, S. (2013). Comparative financial performance of national banks before, and after the global financial crisis. Journal of Economic Balance, 9(1), 1-10.

Cholifah, A. Nurul and Suhadak. (2017). Analysis of banking financial performance before and after the formation of the joint venture (study at PT. Bank Mandiri (Persero) Tbk for the period 2014 - 2016). Journal of Business Administration, 42 (1), 115-124.

Dendawijaya, L. (2013). Banking management. Jakarta : Ghalia Indonesia

Dewi, I A G Kesuma and Purnawati, Ni Ketut. (2016). Analysis of banking financial performance before and after the acquisition at Bank Sinar Bali. E-Journal of Management Unud, 5(6), 2504-2531.

Fahmi, Irham. (2013). Financial statement analysis. Bandung: Alfabeta, CV.

Hasanah, L. (2011). Comparative analysis of the financial performance of Islamic business units based on aspects of liquidity, solvency and profitability before and after the 2008 global crisis. Thesis. Universitas Indonesia.

Kinasih, A Dian. (2013). Analysis of bank financial performance before and after the global crisis (study on national private commercial banks listed on the IDX for the period 2007-2009). Thesis. Program Pasca Sarjana Magister Management UNDIP Semarang. Page 1-15.

Kresmiati, Nita. (2017). Comparative financial performance before and after the 2008 global financial crisis on the PT. Bank Syariah Mandiri. ). S1 Thesis. IAIN Tulungagung.

Kuncoro, M. (2010). Research methods for business and economics. Jakarta: Erlangga. 
Kurniasari, A Wida. (2017). Comparative analysis of the financial performance of Islamic banks before and after the spin-off (at Bank Jabar Banten Syariah). S1 Thesis. Institut Agama Islam Negeri Surakarta.

Lombogia, R. (2015). Comparative analysis of financial performance based on credit risk, market risk, liquidity risk, and liquidity coverage ratio (a case study in state-owned banks to go public before and after the implementation of the OJK). Journal of EMBA, 3(3), 798-806.

Munawir. (2012). Financial statement analysis. Yogyakarta: Liberty Yogyakarta.

Nasser, E M. (2013). Comparative performance of state banks and private banks with the camel ratio and its effect on stock prices. Media Research Accounting, Auditing and Information, 3(3).

Novriza. (2012). Comparative analysis of the financial performance of state banks and private banks before and after the global crisis. S1 Thesis. Universitas Lampung.

Prima, A Bella. (2018). Analysis of the financial performance of banks in Indonesia before and after the merger (the study on domestic companies merge with foreign ownership). FEB Student Science Journal Universitas Brawijaya, 6 (2).

Putri, N Nurul. (2020). The impact of the corona pandemic on the Indonesian economic sector. Accessible via https://sukabumiupdate.com/detail/bale-warga/opini/67504Dampak-Pandemi-Corona-Terhadap-Sektor-Ekonomi-Indonesia on May 10, 2020.

Rahmawati, C Diah dan Sulistiyo, A Budi. (2015). Comparative analysis of Islamic banking financial performance before and after the global economic crisis (case studies of Bank Muamalat Indonesia, Bank Syariah Mandiri, Bank Mega Syariah 2006-2010). Student Scientific Articles, 1-6

Rasim. (2015). Indonesian banking financial performance before and after the global crisis in 2008 (a case study in state banks in Indonesia period 2003-2013). S1 Thesis. FEB Unila.

Salin, A. (2018). Differences in banking financial performance before and after the implementation of good corporate governance (GCG) (a case study at Bank Syariah Mandiri). Journal of Ekomadania, 1( 2),149-176

Sisbintari, I. (2012). Comparative analysis of CAR, LDR, ROA and ROE before and after the merger at PT. Bank Cimb Niaga Tbk. Profit : Journal of Business Administration , 6 (2), 163-173.

Sitanggang, L M Sautlan. (2020). The performance of state-owned banks remained positive until the 1st quarter of 2020. Accessed via https://keuangan.kontan.co.id/news/kinerja-bank-pelat-merah-masih-positifsampai-kuartal-i-2020 on May 30, 2020.

Sugiyono. (2014). Statistics for research. Bandung: Alfabeta 
Sulistiyo, C Bagus. (2020). Bank's Strategy in Facing Covid-19. Accessible via https://analisis.kontan.co.id/news/strategi-bank-menghadapi-covid-19 on May 10, 2020

Syafina, D Chadiza. (2020). When the Covid-19 hit the banking sector in various countries. Accessible via https://tirto.id/ketika-corona-covid-19-menghantam-sektor-bank-diberbagai-negara-eE1H on May 10, 2020.

Ucu, K Raharja. (2020). Economic stimulus plague corona: the banking industry. Accessible via https://republika.co.id/berita/q7iu7z282/stimulus-ekonomi-wabah-coronaindustri-perbankan on May 10, 2020.

Utami, E. (2013). Comparative analysis of financial performance at PT. Bank Pundi Indonesia Tbk. before and after acquisition. S1 thesis, Universitas Pendidikan Indonesia.

Widiani, N K Linda; Purnamawati, I G Ayu \& Sujana, Edy. (2016). Comparative analysis of Indonesian banking financial performance before and after the global crisis (study at Indonesian state-owned banks the period 2002-2014). Journal of Undiksha, 5(2), 20-32

Ziyad, M. (2010). Comparative analysis of Bank Muamalat's financial performance before and after the issuance of the fatwa on the prohibition of bank interest by the MUI. Journal of Management and Accounting, 11(1), 46-52. 